\section{OPEN \\ JOURNAL \\ SYSTEMS}

ISSN:2237-2202
Available on line at Directory of Open Access Journals

Journal of Hyperspectral Remote Sensing v.8, n.1 (2018) 1-13

www.periodicos.ufpe.br/revistas/jhrs
Journal of

Hyperspectral

Remote Sensing

\title{
Use of vegetation indices to estimate the live biomass loss in the Picuí municipality
}

\author{
Thyago de A. Silveira*, Frederico C. Pereira**, Alexandre F. D’Andrea***, Franscico de Assis S. de Sousa**** \\ "Professor of the Federal Institute of Paraíba - IFPB, Natural Resources Doctorate Student of the Federal University of \\ Campina Grande - UFCG, R. Aprígio Veloso, 882 - Universitário, Campina Grande, Paraíba, Brasil, 58429-900. Email: \\ thyago.silveira@gmail.com (Corresponding author). \\ ***Professor of the IFPB. Email: fredcampos2000@yahoo.com.br. \\ *** Professor of the IFPB. Email: alexandre.dandrea@ifpb.edu.br. \\ *****Professor of the UFCG. Email: fsouza2011@gmail.com.
}

Received 15 April 2018; accepted 22 May 2018

\begin{abstract}
The desertification or land degradation is a phenomenon that has been occurring in many parts of the planet. This process has been accompanied by climatic factors and socio-ecological, and in the Northeast of Brazil is considered a phenomenon resulting from human intervention over the environment. This work was proposition estimate the amount of live biomass lost in the city of Picuí - PB from the multitemporal analysis of vegetation cover using satellite images. For both GIS and Remote Sensing techniques were used, with the purpose of calculate soil degradation over the past three decades, and calculate the NDVI, SAVI and IAF vegetation index, to estimate the amount of living biomass lost over in the period studied. As a result, it was verified that the city has about $30 \%$ of its land in degradation level ranging from grave and very grave, and that the living biomass decreased by about $20 \%$ in these past three decades, coming to present about $49 \%$ of green area, and about $51 \%$ of degraded areas considered, a fact that has been proven through technical visits, which identificated that the areas are degraded by vegetal extraction of wood, mining and agriculture.

Keywords: desertification, environmental degradation, vegetation index, Picuí-PB.
\end{abstract}

\section{Introduction}

Since the beginnings, humankind has used the environment that surrounds it to extract its survival. In this conflict, man has established a dependence relationship with the environment, and through his socioeconomic decisions has become the main beneficiary, in order to bring transformations and adaptations to his favor.

If initially the transformations were insignificant, over the years they became more intense, of form to be felt and noticed every day (Melphi, 2009). In promoting these impacts, the humankind has become a producer of degradation processes in the environment.

This process of environmental degradation has been intensifying throughout the world due to anthropic actions, and aggravated by the exploitation of natural resources, which aim at survival and commercialization, has contributed to the expansion of areas that will be, in the short time, Involved in a desertification process.

The United Nations Convention to Combat Desertification (UNITED NATIONS, 2001) defined desertification as the process of land degradation in dry, semi-arid and dry sub-humid regions, resulting from different factors, including climatic variations and human activities.

This event can be considered as a combination of processes, including those resulting from human activities and settlement patterns, such as: (a) soil erosion caused by wind or water; (b) the deterioration of the physical proprieties, chemical and biological properties or economic properties of the soil, and (c) the lasting loss of natural vegetation (FAO, 2005).

At the highest levels, desertification causes social, economic, cultural, political and environmental impacts, that are related to each other, and over the years, has been intensified and increased the population vulnerability, causing great social and economic losses, for the Northeast region (Sousa, 2007), as well as the reduction of the quality of life of the affected population.

In Brazil, areas sensitive to desertification include the states of Maranhão, Piauí, Ceará, Rio Grande do Norte, Paraíba, Pernambuco, Alagoas, Sergipe, Bahia, Minas Gerais and Espírito Santo. These spaces cover a total of 1.482 municipalities, of which $38,42 \%$ present a severe level of environmental degradation linked to monoculture; $5,86 \%$ in a very serious condition in relation to the degree of committed territory of the northeastern semi-arid. 
In this context, Paraíba appears as the third Northeast State with the highest number of municipalities included in the semi-arid area. According with data from the National Action Program to Combat Desertification and Mitigate the Drought Effects (PAN-BRAZIL, 2005), 208 districts sensitive to desertification were identified, divided into the following areas: in semi-arid areas there are 150 municipalities, in droughts sub-humid areas 47 municipalities and in the surrounding areas 11 municipalities. Thus, are affected directly about 1,5 million people.

In a diagnosis carried out by the Paraíba Environmental Superintendence (SUDEMA-PB, 2008), about $57,06 \%$ of its territory has a very high degree of susceptibility to desertification, which extends from the Western Seridó to the Sousa microregion.

This region is characterized by high evapotranspiration, occurrence of drought periods, surface soils and less water retention capacity, which limits its productive potential. These interconnected elements reveal a very resistant ecosystem, periodically aggravated, mainly due to the degradation of the vegetation cover and the land incorrect uses, through the predatory exploitation of the caatinga, deforestation and burning.

In the municipality of Picuí, the problem is no different, otherwise, it is estimated that the exploitation of natural resources has gradually increased in recent years, which has caused the increase of areas with uncovered soils and a greater daily thermal amplitude that characterize areas in the desertification process.
The increase of areas in the desertification process and the reduction of green and cultivable areas bring serious consequences for the rural population located in the agroecological communities of the Picuí municipality, who often need to move to the urbanized center, avoiding the reality of drought, abandoned its rural properties with no strategy for the recovery of degraded areas.

In this sense, to verifying the temporal evolution the living biomass amount of the areas in the desertification process, and to study its effects through the application of a monitoring model of biological desertification indicators, of vegetation cover proposed by Matallo Junior (2001) he holistic understanding of historical facts is expected, as well as the elaboration of concrete measures that can aware farmers, residents, authorities, local government and students of the current state of these areas, in contrast, build an environmental process to mobilization and systematization, proposing solutions to deal with and recover the degraded areas.

Thus, the objective of this work was to estimate the amount of live biomass lost in the Picuí municipality, from the multitemporal analysis of the vegetation cover using satellite images.

\section{Materials and methods}

The Picuí municipality is in Borborema Mesoregion and Eastern Seridó Microregion, at an altitude of $440 \mathrm{~m}$ above sea level, doing border with the Western Curimataú Microregion (Figure 1).

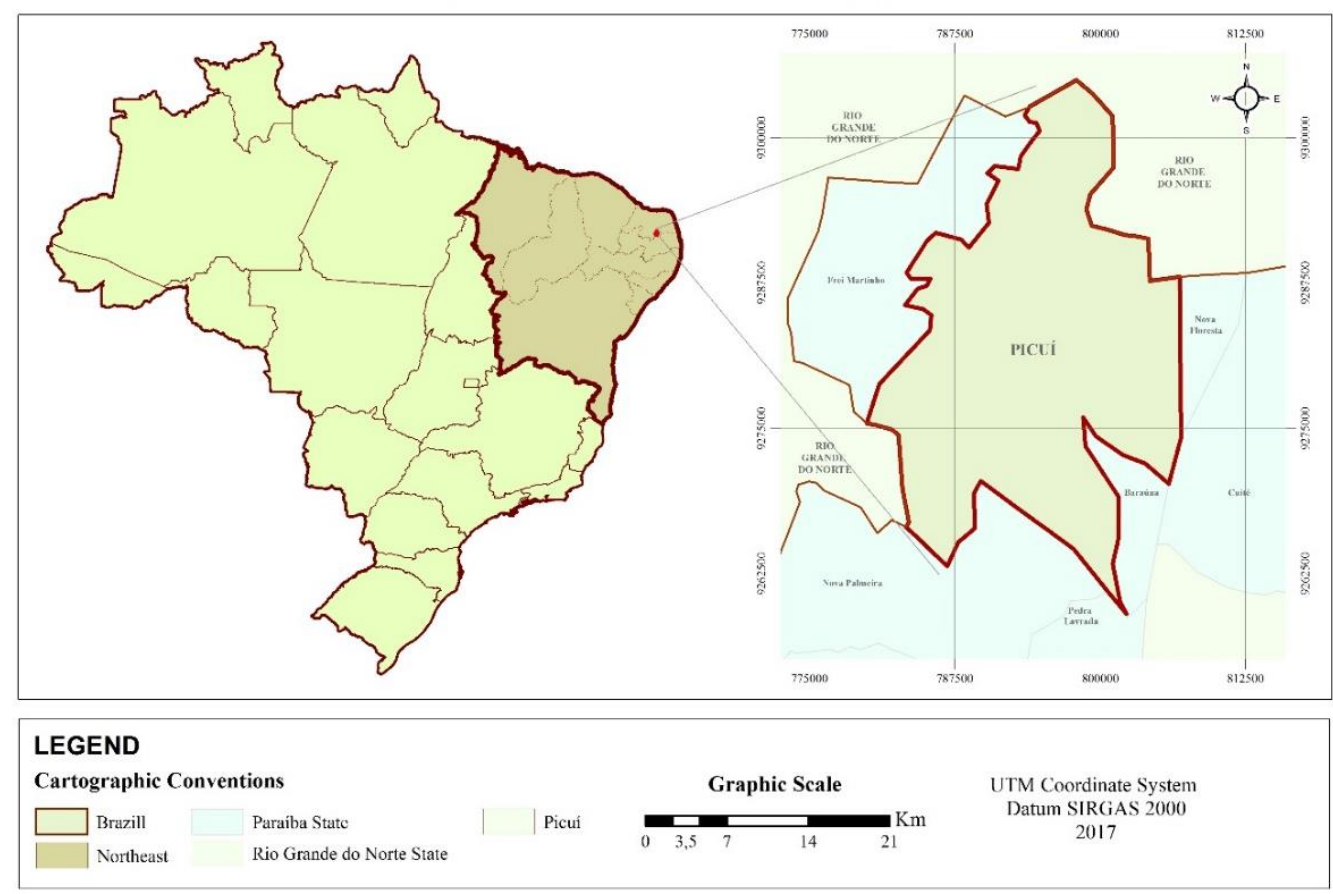

Figure 1 - Study area, Picuí municipality, Paraíba. 
Is limited in north with Rio Grande do Norte state, in south with Nova Palmeira, Pedra Lavrada and Baraúna municipalities; in east with Cuité and Nova Floresta municipalities; and the west, with Frei Martinho municipality, and again with the Rio Grande do Norte state.

The Picuí city is characterized as the development pole of the Seridó Paraibano and the Western Curimataú microregions. Support to 16 municipalities in these microregions. According to the IBGE (2010), its population is of 18.226 inhabitants, and its territorial area is of $666 \mathrm{~km}^{2}$. The municipality is included in the geographic area covered by the Brazilian semi-arid region, defined by the National Integration Ministry in 2005, whose had how criteria the pluviometric index, aridity index and risk of drought (PAN-BRASIL, 2005).

The municipality's economy is concentrated in three major activities: rural work, domestic work and work in the municipal public sector. There is also the economic activity of mining, which develops at an incipient stage, in exploratory and informal way. This activity is expanding every year, always reaching new areas that were not previously explored, without promoting local sustainability.

It is in this region, where the Caatinga biome predominates, where resilient areas are found, which have undergone a wide environmental degradation process through the soil desertification, and which are gradually aggravated by irregular agricultural practices and unrestricted plant extraction.

For the Picuí environmental characterization, were obtained SRTM images satellite for relief morphometric characterization, representative Landsat 7 satellite images for 90 and 2000 decades, of the ETM (Enhanced Thematic Mapper) and CBERS 2B sensors of the High Resolution CCD sensor) representing the Decade of 2010, everything corresponding to postrainy periods, referenced to the World Geodetic Datum System (WGS-1984), to 215 and 65 orbit, and to a 30meter spatial resolution (Landsat 7) without cloud cover.

The images of the Landsat satellite helped to make mosaics (a combination of two or more images to compose a single combined image) of the years 1990, 2000 and 2010 to verify and identify how the process of degradation of the areas occurred in the municipality of Picuí - PB, and consequently how the loss of living biomass occurred during this period.

The Landsat 7 satellite image is composed of seven bands $(1,2,3,4,5,6,7)$ and the CBERS 2B satellite image consists of four bands (4, 3, 2 and 1). The three-band junction forms a colored image or composition, which is based on the of primary addition bands R (red-red), G (green-green), B (blue-blue) 4,3 and 2 .

After the establishment of the colored images, they were subjected to several combinations of contrasts, so that they were maximized and which are gradually aggravated by irregular agricultural practices and unrestricted plant extraction obtain clear images in which the target vegetation, the exposed soil and the water bodies were easily identified.

Then, they went through the georreferencing phase, which is a procedure that eliminates the existing distortions, caused by the movement of the satellites, caused in the process of image formation. All images were georeferenced in the UTM Coordinate System and referenced to DATUM Sirgas 2000.

Subsequently, individual cuts were made in each of the images, to delineate the Picuí Municipality area, and generate the Images Charts for the decades studied.

To verify the degradation levels during the three decades, supervised digital classifications were carried out, using the Maximum Likelihood (Max Ver) method, to define the degradation class areas. Subsequently, bands 3 and 4 of the respective images were used to calculate vegetation indexes.

The monitoring and evaluation of areas desertification process in was being built, gradually, in different ways. Several indices were applied and basic indicators emerged that allowed a global outline of the socioeconomic and environmental profile of desertification.

In order to make accurate diagnoses of the areas process of desertification, in order to use known parameters that are and accepted internationally, UNESCO has adopted standards to standardize the monitoring of desertification processes in the Latin American region.

According to Matallo Junior (2001), the indicators used to identify and monitor desertification processes are divided into two groups: Situation Indicators and Desertification Indicators.

The Situation Indicators comprise the adoption of parameters related to climatic and socioeconomic data. Climate indicators help to define of degradation levels, and are, therefore, constantly monitored, and the social and economic indicators help it's in the local phenomenon characterization. In turn, the Desertification Indicators, favor of the phenomenon identification at environmental level, through the vegetation characterization, soils and water resources (Matallo Junior, 2001).

As this work shows live biomass, the class of indicators of desertification indicated is the class of Biological Indicators, presented in Dataframe 1. 
Dataframe 1 - Desertification situation indicators.

\begin{tabular}{|c|c|c|c|c|}
\hline \multicolumn{5}{|c|}{ DESERTIFICATION INDICATORS } \\
\hline Indicators & Definition & $\begin{array}{c}\text { Unit of } \\
\text { measuremnt }\end{array}$ & Method & $\begin{array}{c}\text { Collection } \\
\text { period }\end{array}$ \\
\hline \multicolumn{5}{|c|}{ Desertification Biological Indicators } \\
\hline Vegetal cover & $\begin{array}{l}\text { Percentage of a given area with native } \\
\text { vegetation cover. Changes in the original } \\
\text { vegetation cover are the first indications of } \\
\text { human occupation. Its fundamental } \\
\text { importance is in the protection that it exerts } \\
\text { on the soil against the erosive effects. Its } \\
\text { elimination or reduction, accompanied by } \\
\text { inadequate techniques of land use and } \\
\text { management, allows the initiation and } \\
\text { acceleration of desertification processes. }\end{array}$ & $\begin{array}{l}\% \text { of native } \\
\text { vegetation } \\
\text { cover in } \\
\text { relation to } \\
\text { the total area }\end{array}$ & $\begin{array}{l}\text { Orbital } \\
\text { images }\end{array}$ & $\begin{array}{c}\text { Every } 5 \\
\text { years }\end{array}$ \\
\hline $\begin{array}{l}\text { Vegetation } \\
\text { stratification }\end{array}$ & $\begin{array}{l}\text { Number of strata in a given area. In } \\
\text { general, desertification processes } \\
\text { standardize vegetation in terms of strata } \\
\text { and number of species. The most degraded } \\
\text { areas have * a single stratum Number of } \\
\text { strata }\end{array}$ & $\begin{array}{c}\text { Strata } \\
\text { Number }\end{array}$ & $\begin{array}{c}\text { Land search } \\
\text { by territory } \\
\text { sample }\end{array}$ & $\begin{array}{c}\text { To } \\
\text { determine }\end{array}$ \\
\hline $\begin{array}{c}\text { Specific } \\
\text { composition }\end{array}$ & $\begin{array}{l}\text { Native species in the area. By extinction or } \\
\text { by natural elimination of the system, the } \\
\text { species tend to decrease over time. It is } \\
\text { related to anthropism and inadequate } \\
\text { management methods. }\end{array}$ & $\begin{array}{l}\text { Species } \\
\text { number }\end{array}$ & $\begin{array}{c}\text { Land search } \\
\text { by territory } \\
\text { sample }\end{array}$ & $\begin{array}{c}\text { To } \\
\text { determine }\end{array}$ \\
\hline Species indicators & $\begin{array}{l}\text { Species associated with the degradation } \\
\text { phenomenon of an ecosystem. There are } \\
\text { species that indicate the process of soil } \\
\text { impoverishment, either by loss of fertility, } \\
\text { erosion or salinization. }\end{array}$ & Species & $\begin{array}{c}\text { Land search } \\
\text { by territory } \\
\text { sample }\end{array}$ & $\begin{array}{c}\text { To } \\
\text { determine }\end{array}$ \\
\hline
\end{tabular}

SOURCE: Adapted from Matallo Junior (2001).

Once, indicators can be used by the adoption of several combination sequences, excluding for some regions the least favorable ones to be applied. The establishment of this indicators set is conditioned on favoring a consistent process to evaluation and monitoring desertification, in view of estimate living biomass (vegetation) through the vegetation cover indicator. This indicator can be evaluated by estimating the amount of live biomass lost over the years through the Digital Image Processing (DPI) of the LANDSAT 5 and 7 and CBERS satellites, which are available for download on the Instituto Nacional de Pesquisas Espaciais (INPE) website.

Indicators or vegetation indexes represent a technique widely used in the area of Remote Sensing, since they indicate the presence and conditions of monitored vegetation, based on the fact that the primary production of a vegetal community has a close relation with the solar energy absorbed, which defines the development of this community (Fontana et al., 1988).

For the living biomass analysis of a certain region, the following indices are used:

1. Normalized Differentiated Vegetation Index (NDVI), proposed by Rouse et al. (1973), which is calculated by the difference of identified reflectance in the satellite images, in bands presenting the near infrared (NIR) and red bands in the visible band (VIS) divided by the sum of the bands NIR and VIS, as presented in Eq. 1: 


$$
\mathrm{NDVI}=(\mathrm{NIR}-\mathrm{VIS}) /(\mathrm{NIR}+\mathrm{VIS})
$$

2. The Soil Adjusted Vegetation Index (SAVI) proposed by Huete (1988), introducing a factor in the NDVI to incorporate the soil presence effect, maintaining the NDVI value between -1 and +1 . This index is calculated according to Eq. 2:

$$
\text { (NIR-VIS) } x(1+\mathrm{L}) /(\mathrm{NIR}+\mathrm{VIS}+\mathrm{L})
$$

Where, $\mathrm{L}$ is a constant, whose most frequent used value is 0,5 (Accioly et al., 2002; Boegh et al., 2002; Silva et al., 2005).

3. Foliar Area Index (FAI) is a biophysical variable defined as the total of foliar area per land surface area (Watson, 1947). This index is the live biomass indicator, calculated by the empirical equation proposed by Allen et al. (2002), as shown in Eq. 3 .

$$
\mathrm{IAF}=\operatorname{Ln}((0.69-\mathrm{SAVI}) / 0.59) / 0.91
$$

Where, Ln is the Neperian Logarithm.

Finally, after the IAF definition, the corresponding image past a supervised digital classification, also using the Maximum Likelihood method (MaxVer), for the definition of green and degraded areas, being the respective amount of each area was calculated.

\section{Results}

To verify the municipality relief formation was acquired an SRTM image, which received a digital treatment, and resulted in a map altimetric features that can be visualized in Figure 2.

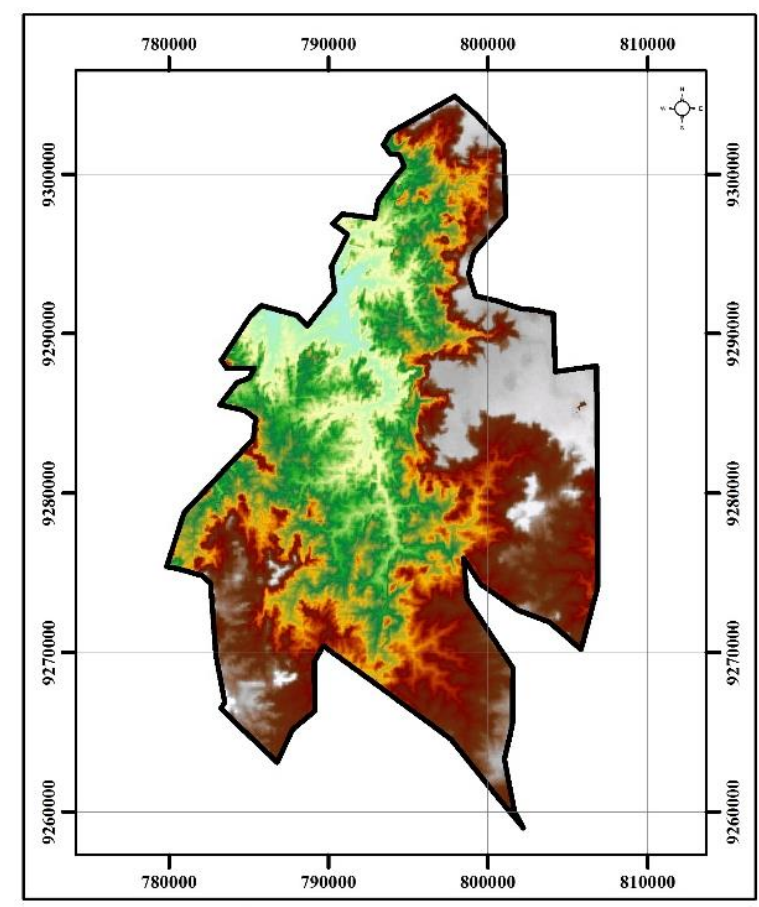

PICUÍ ALTIMETRIC CHARTER

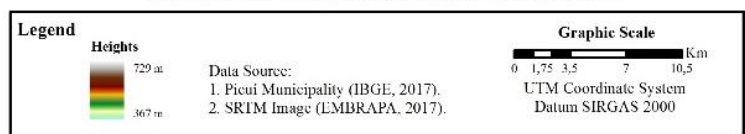

Figure 2 - Picuí altimetric chart.

As can be seen in the Picuí Altimetric Chart the altitudes range from 367 meters above mean sea level, in the lower regions of the municipality (regions in shades of light green) to 729 meters above mean sea level, in higher regions, as can see in shades of brown and white.
With the aim of revealing and estimating how the municipality of Picuí was in the past, and how the change in vegetation cover occurred over three decades, were generated Picuí Municipalities Imagens Chart (Figure 3) and Degradation Class Maps (Figure $4)$. 


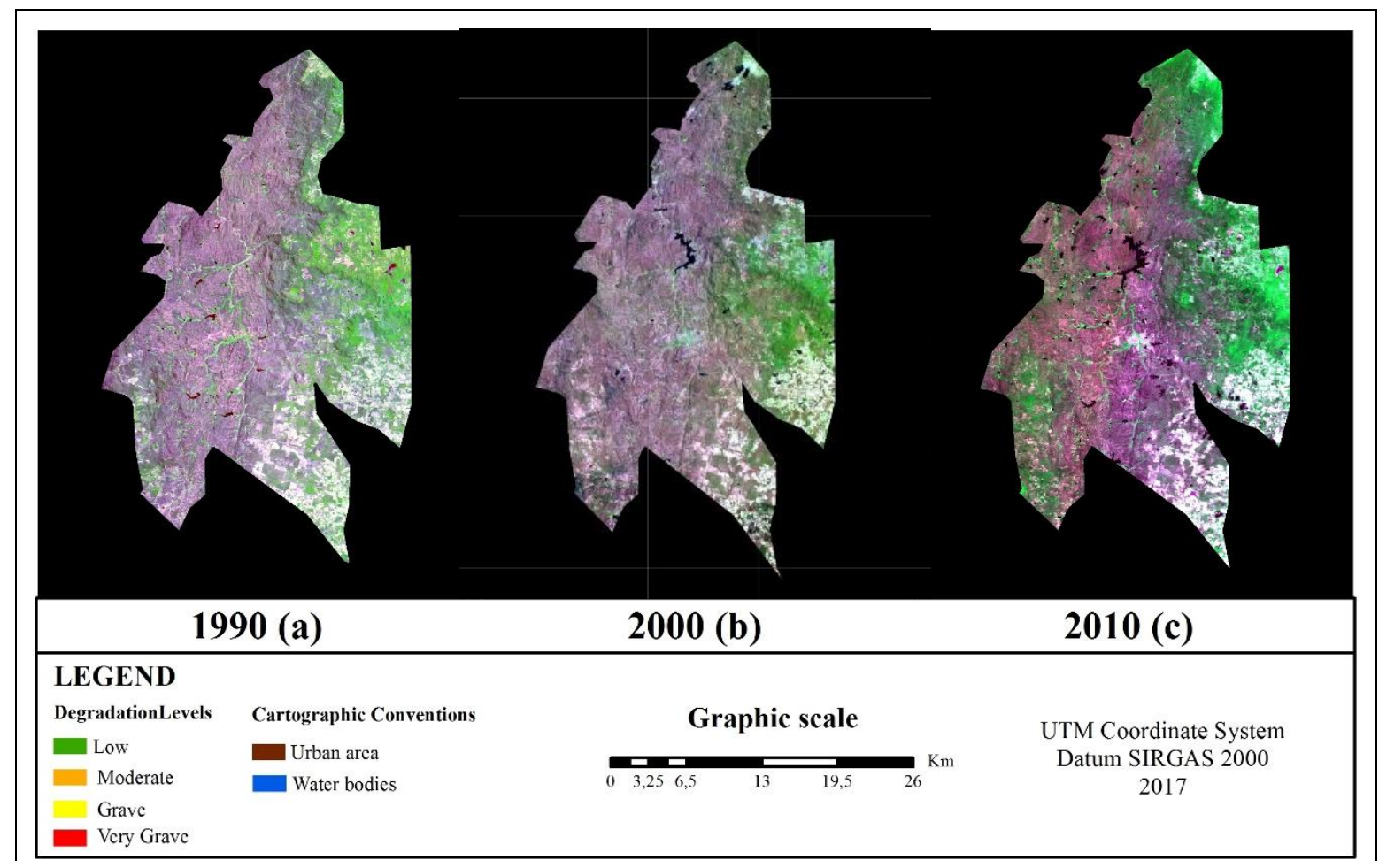

Figure 3 - Imagens chart of Picuí municipality.

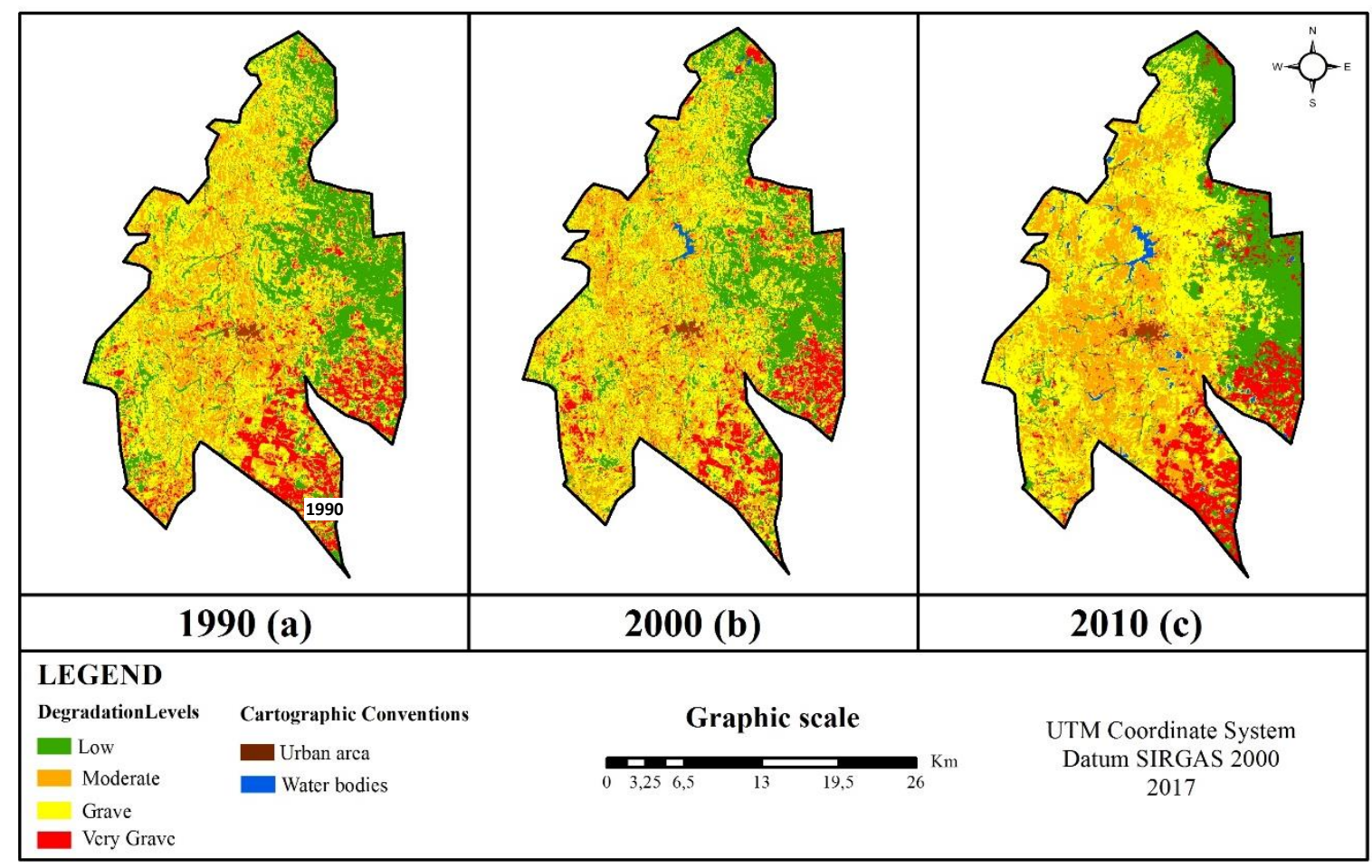

Figure 4 - Degradation classes map of Picuí municipality.

The level of degradation for these three decades was estimated and quantified (Table 1). In general, can be verified from presented data in Table 1, that the environmental degradation of Picuí municipality considered to be severe decreased from $36,38 \%$ in the 1990 s and from $38,03 \%$ in the decade of 2000 to 18 , $81 \%$ Decade of 2010. In contrast, and inversely proportional to the severe class, low and moderate levels have increased considerably. Very serious levels had little variation over the decades studied.

Posteriorly, vegetation indices were also calculated based on the last three decades. The Figure 5 shows the Normalized Differentiated Vegetation Index (NDVI). 
Table 1 - Quantification of the classes of environmental degradation of the Picuí municipality.

\begin{tabular}{lcccccc}
\hline Level of soil degradation & $\begin{array}{c}\mathbf{K m}^{\mathbf{2}} \\
\mathbf{( 1 9 9 0 )}\end{array}$ & $\mathbf{\%}$ & $\begin{array}{c}\mathbf{K m}^{\mathbf{2}} \\
\mathbf{( 2 0 0 0 )}\end{array}$ & $\boldsymbol{\%}$ & $\begin{array}{c}\mathbf{K m}^{\mathbf{2}} \\
\mathbf{( 2 0 0 9 )}\end{array}$ & \multirow{\%}{*}{} \\
\hline Low & 158,03 & 23,87 & 148,62 & 23,61 & 199,360 & 30,14 \\
Moderate & 188,82 & 28,52 & 177,41 & 28,18 & 255,381 & 38,66 \\
Severe & 240,83 & 36,38 & 239,39 & 38,03 & 124,241 & 18,81 \\
Very Severe & 74,19 & 11,20 & 63,96 & 10,16 & 68,119 & 10,31 \\
\hline
\end{tabular}

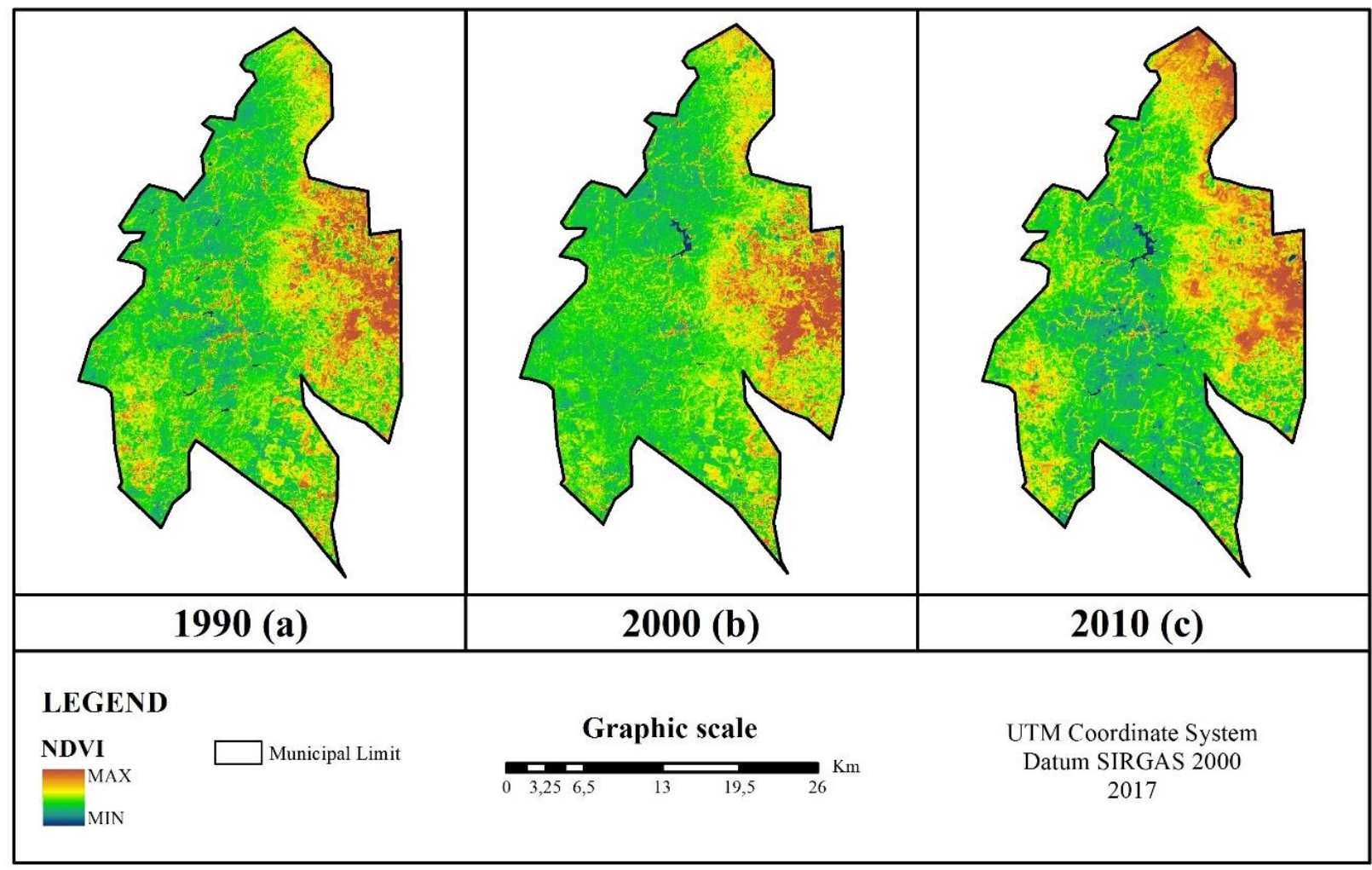

Figure 5 - NDVI calculated for the 1990s (a), 2000 (b) and 2010 (c).

In Figure 4, the NDVI highlight areas with more denser vegetation, presented in yellow and red coloring, which are related to vegetation areas with greater vigor. The degraded areas are presented in green shades, from the lightest to the darkest, where the vegetation is more stressed, less dense, with scarce and spaced vegetation and uncovered soils. The areas with water presence become evident, for they are represented in blue color, and their NDVI responses are presented in the minimum values of the index.

After NDVI calculation, the soils index was also calculated based on the last three decades. Figure 6 shows the Soil Adjusted Vegetation Index (SAVI). 


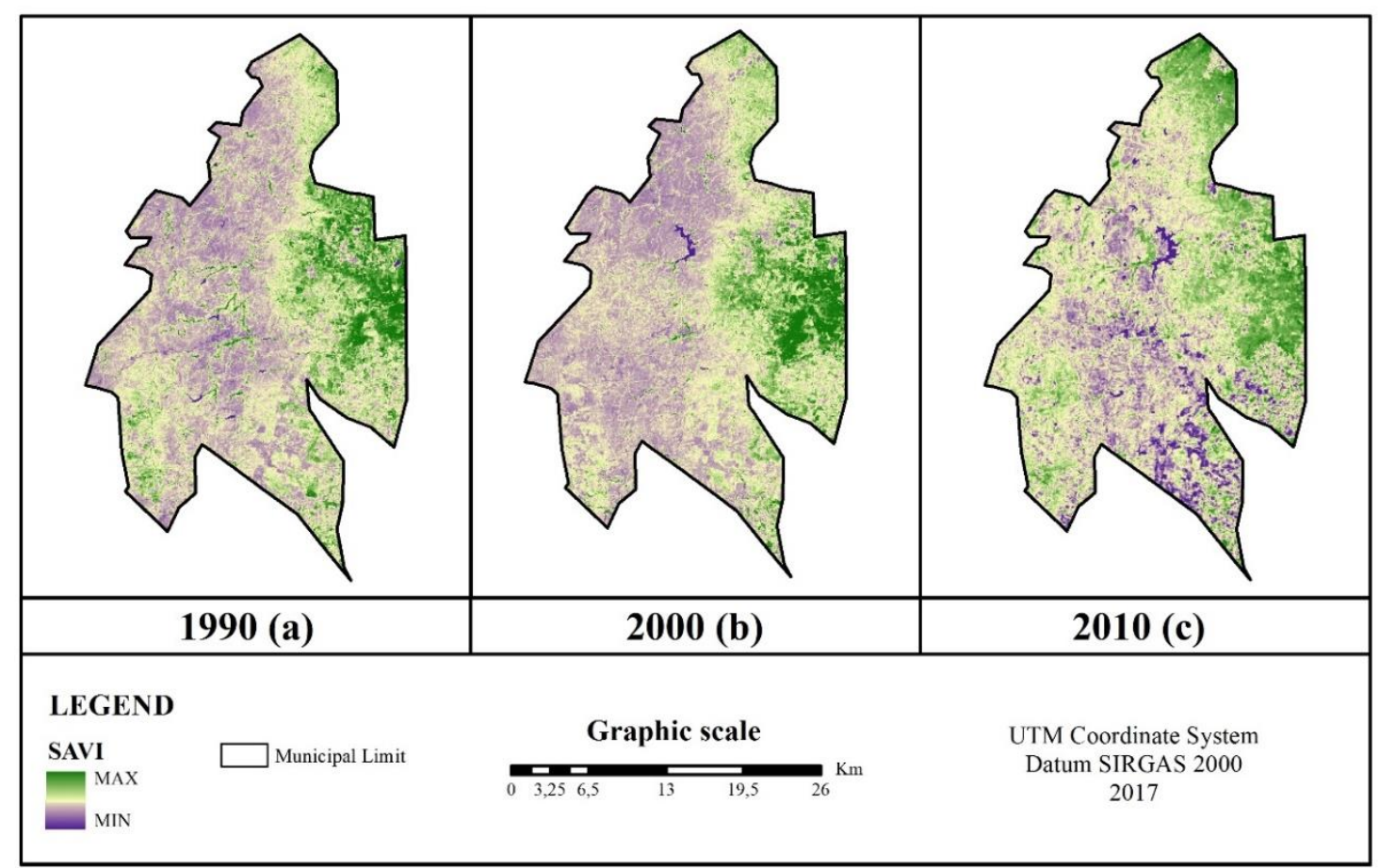

Figure 6 - SAVI calculated for the 1990s (a), 2000 (b) and 2010 (c).

The SAVI minimize the soil reflection effects to consider the incorporation of a dependent adjust factor of vegetation density (Gilabert et al., 2002; Eastman, 2006). The SAVI results express similarities to results obtained with the NDVI values. However, the SAVI highlighted more the exposed soil influence, mainly in the beginning of vegetation development recovery in the studied areas.

As a soil index, the evidence part in green tones, therefore higher index values, represent areas with denser vegetation. Already as purple shades, lighter to darker, present areas with a vegetation that is found more sparse or exposited soil. The minimum SAVI values represent the water bodies.

After SAVI calculation, were calculated the foliar area index (FAI), also based on the last three decades. Figure 7 shows the FAI, which identifies an amount of live biomass present in the images.

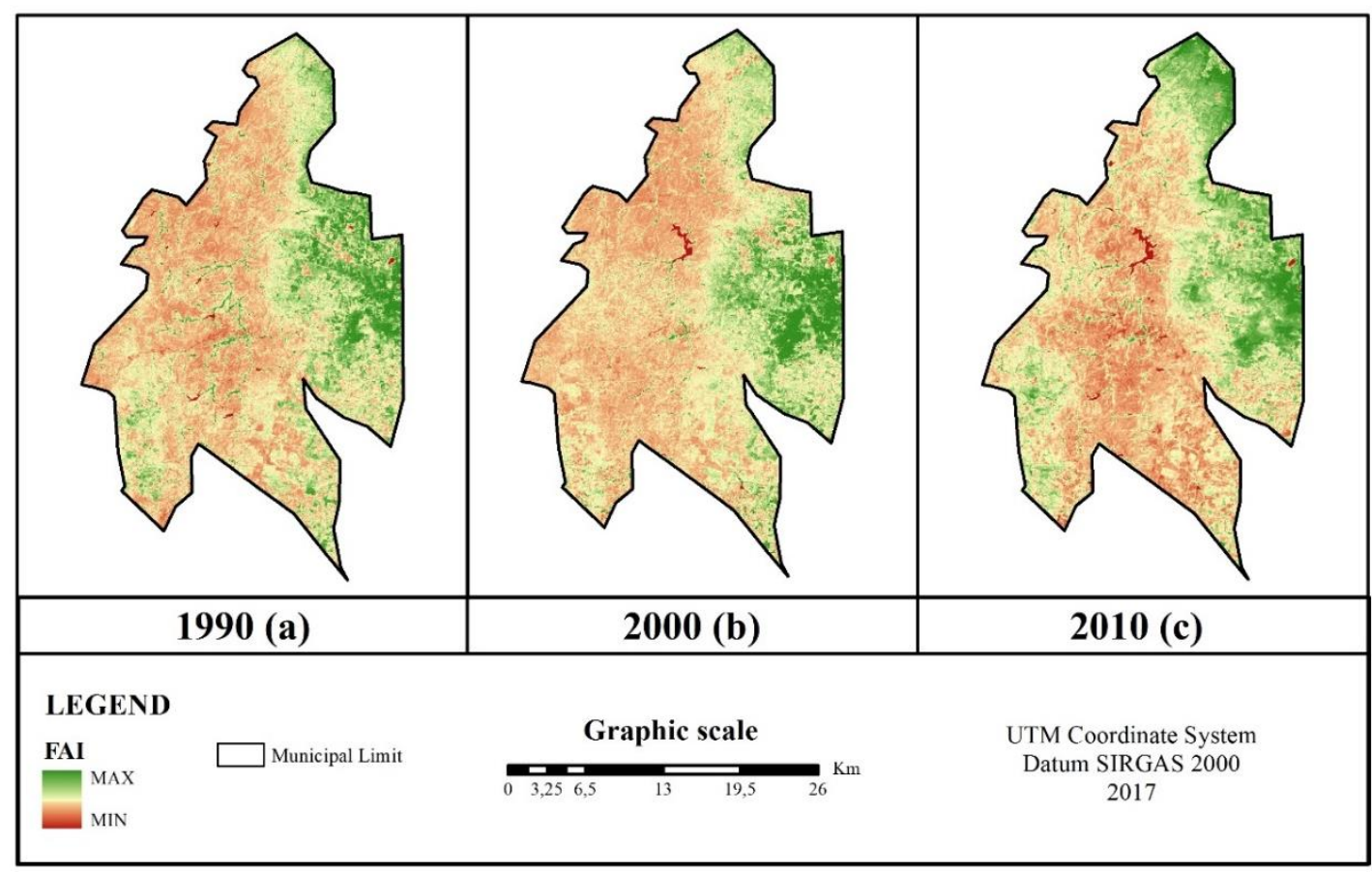

Figure 7 - IAF calculated for the 1990s (a), 2000 (b) and 2010 (c). 
As the IAF is a sub-product of the NDVI and SAVI, the analyzes of the obtained results for this index are very similar to the results already defined in Figures 5 and 6 . However, for being an index related to present vegetation amount in the Picuí municipality, this factor be evidence in the LAI representativeness, since it is defined by the ratio between foliar area of all vegetation per area unit used by this vegetation.

Thus, the presented data in the images in the green shade resemble with the correspond areas data where the vegetation presence is more exuberant, denser and preserved due the better water availability in soil profile, consequently this condition favored a better vegetative vigor, providing a greater live biomass. Yellows and reds areas, whose vegetation presence occurred of spaced way, supplied and contrasted with the exposed soil, configuring areas in environmental degradation process.

After the IAF establishment, were realized in the images of the 1990s, 2000s and 2010s supervised digital classifications, using the Maximum Likelihood methodology (MaxVer), in view of the quantify of degraded and green areas, can be observed in Figure 8.

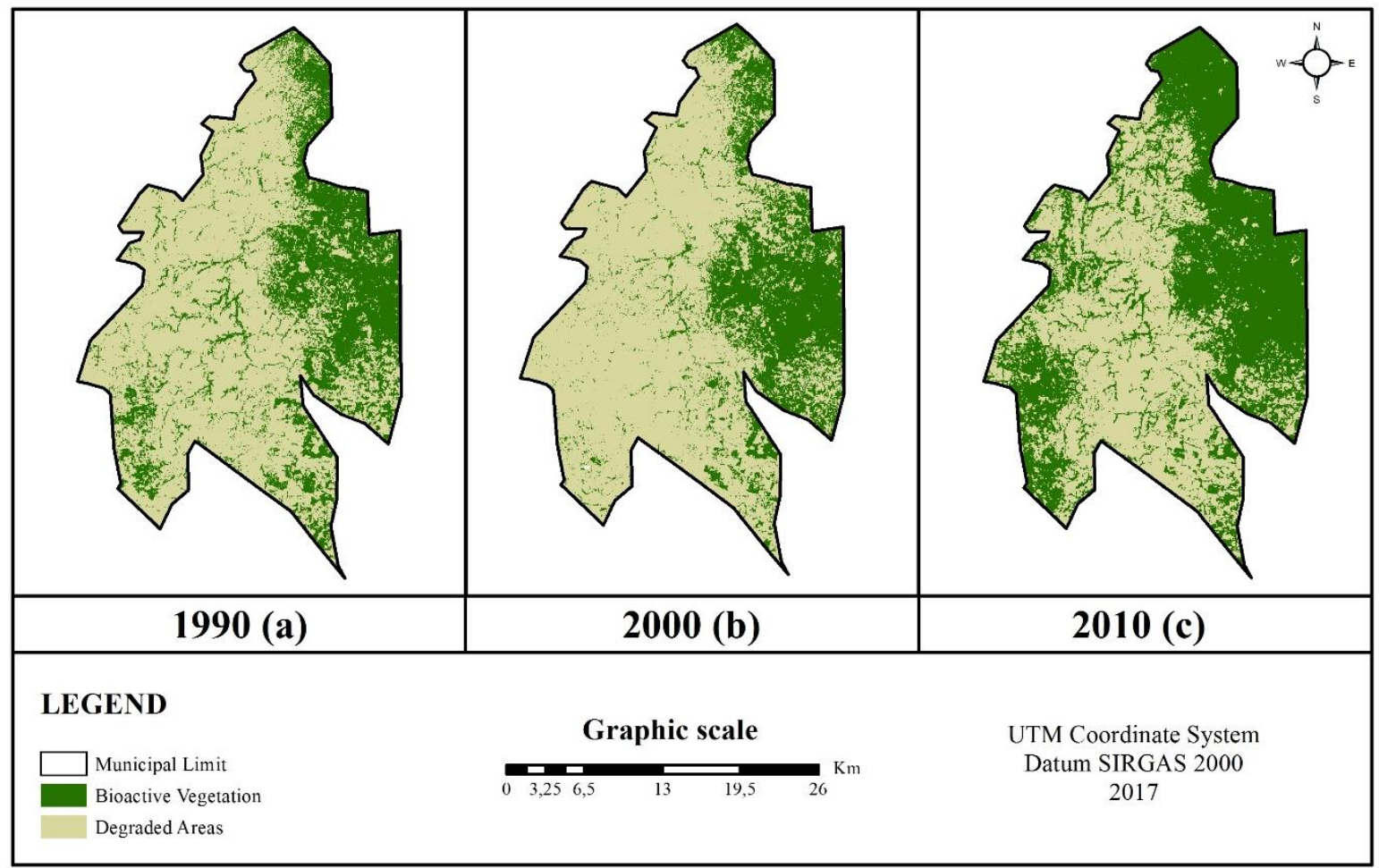

Figure 8 - Living biomass map of Picuí in the 1990s (a), 2000 (b) and 2010 (c).

The Living Biomass Map of Picuí Municipality presents all areas with vegetation, in green color, that during the first two decades has suffered losses in its vegetation structure, giving rise to appearance degraded areas, present in light yellow color. With the Living Biomass Map, it was possible to estimate, in $\mathrm{km}^{2}$, the Degraded and Green classes, Degraded and Green, quantified according to Table 2.

Table 2 shows that the Living Biomass of Picuí in the beginning 1990 s was $203,95 \mathrm{~km}^{2}$, representing $30,81 \%$ of total area of the municipality. Ten years later, Living Biomass accounted for $27,55 \%$ of the total municipality area, which is equivalent to $182,08 \mathrm{~km}^{2}$. This decrease of $21,879 \mathrm{~km}^{2}$ in the municipality Living Biomass was due a dry period after the beginning of the 2000s, which caused a decrease in foliar vegetation structure in the various species.

According Silveira et al. (2013), the peak of land degradation presented was in 1990s in the municipality, mainly due degradation by agricultural cultivation, agriculture by monoculture, and by creation of bovine and goats herd's pastures, by all Seridó Region past in the 1970 and 1980 decades.

In the 1990s, farmers faced land and production stagnation, abandoning areas previously reserved for production, because weren't found strategies for recovery the degraded areas, and the rural extension didn't to meet this specific demand from farmers.

In the 2000s, after suffering without having no lands for planting, farms often terminated extracting dry vegetation for illegal commercialization, whose growing exploration of the ceramist industry also evolved in the 1990s and 2000s. This industry kind uses the illegal extraction from the caatinga wood, and the clay removal from the reservoirs bottom, to stimulate the creation of informal and illegal jobs, which has significantly contributed to the reduction of areas where degradation is low, Contributing significantly to the increase of degraded areas, and consequently with areas in desertification process. 
Table 2 - Quantification of the environmental degradation classes of Picuí municipality, for the 1990s, 2000s and 2010s.

\begin{tabular}{ccccccc}
\hline Description & $\begin{array}{c}\mathbf{1 9 9 0} \text { Decade } \\
\text { Area }\left(\mathbf{k m}^{2}\right)\end{array}$ & $\%$ & $\begin{array}{c}\mathbf{2 0 0 0} \text { Decade } \\
\text { Area }\left(\mathbf{k m}^{2}\right)\end{array}$ & $\%$ & $\begin{array}{c}\mathbf{2 0 1 0} \\
\text { Decade } \\
\text { Area }\left(\mathbf{k m}^{2}\right)\end{array}$ & $\%$ \\
\hline Degradad Area & 203,95 & 30,81 & 182,08 & 27,55 & 327,05 & 49,41 \\
Green Area & 457,95 & 69,19 & 479,84 & 72,45 & 334,86 & 50,59 \\
\hline TOTAL & $\mathbf{6 6 1 , 9 1}$ & $\mathbf{1 0 0}$ & $\mathbf{6 6 1 , 9 1}$ & $\mathbf{1 0 0}$ & $\mathbf{6 6 1 , 9 1}$ & $\mathbf{1 0 0}$ \\
\hline
\end{tabular}

At the beginning of the 2010 s, observed there was an increase in Living Biomass of Picuí, and the area with was $82,08 \mathrm{~km}^{2}$ in $2010 \mathrm{~s}$, past has $327,05 \mathrm{~km}^{2}$, which represents $49,41 \%$ of the green area of the municipality. Associating these values with the meteorological and climatological events in first 2010 years, verified that the Seridó Oriental Paraibano region past a rainfall constant period, which provided in the several vegetal Caatinga species an increase in its foliar structure.

Therefore, in this humid period with the water presence in the native plants of region, occurred the mesophilic development, the high photosynthesis production by chloroplasts, and the increase of the forest cover, corresponding to highest part of the Caatinga's trees (Moreira and Assunção, 1997).

Even so, the rains distribution occurred very irregularly, raining more in seasonal periods, approximately every ten years, leading the residents, who live mainly from the familiar agriculture, to look for survival alternative forms.

In Picuí, one of the economic alternatives, and of subsistence, for survival are the open-cast mining. Mining contribute significantly to environment degradation, since it is a developed activity through rudimentary techniques, with the most drastic consequences the deforestation of ciliary woods and contamination of the surrounding environment by chemical compounds.

This exploration process is divided between family farming, which occurs during the rainy season, and the mining, that has been a developed activity in the dry, rudimentary period as an informal activity, without the use of appropriate techniques that consider the correct management chemicals products, and the preservation and recovery of the areas used.

To analyze these contrasting spaces, correlating them with the biomass increase process and degraded reduction areas, and to validate the vegetation indices uses, were realized three technical visits. The first technical visit took on 05/04/2015. On that occasion, the André's Lagoa 1, André's Lagoa 2 and Bernadino's mine, shown north of the Picuí, were visited. In the Degradation Classes Map of Picuí Municipality (Figure 4) these areas appeared as be identified by low to moderate degradation levels. Figure 9 shows the visited areas, in which was identified few areas are degraded around the mines.

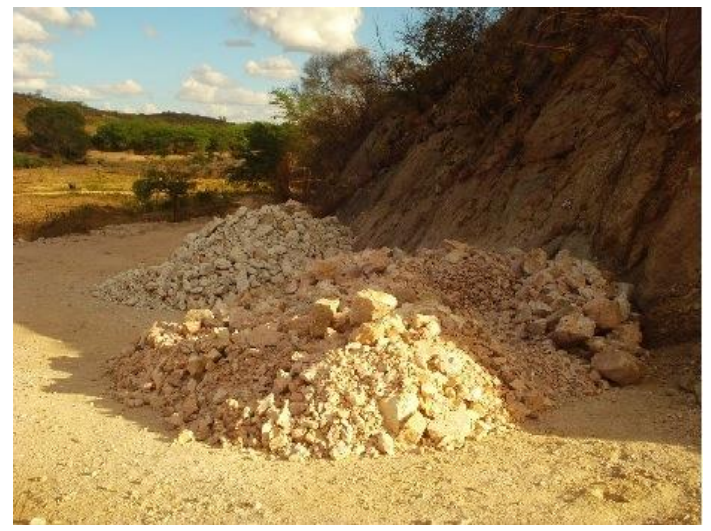

(a)

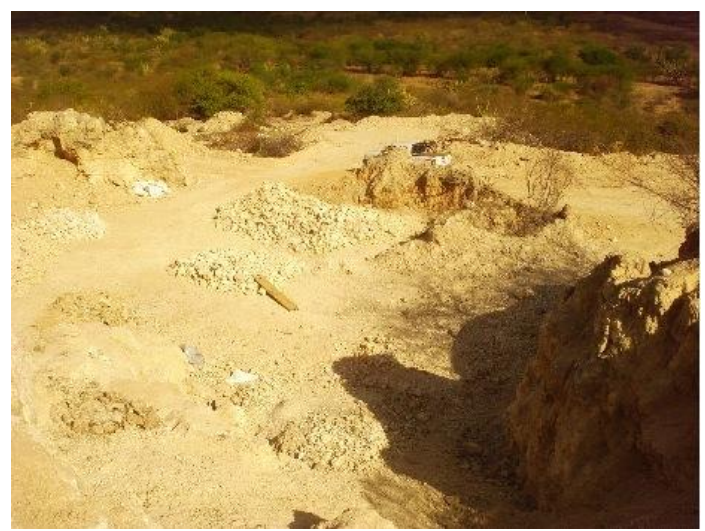

(b)

Figure 9 - Feldspar extraction in the André's Lagoa mine 1 (a) and panoramic view of the André's Lagoa 2 mine (b).

The second technical visit happened on 05/19/2015, in which the Caboclo's Tanque mine was visited, shown to the east of the Picuí city. As there were areas with a very serious level of environmental 
degradation, located nearby, took the opportunity to

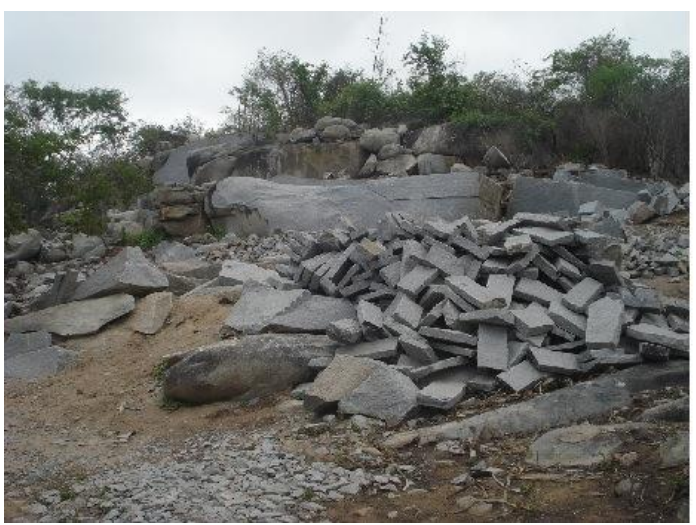

(a) visit them. Figure 10 shows the mine areas visited.

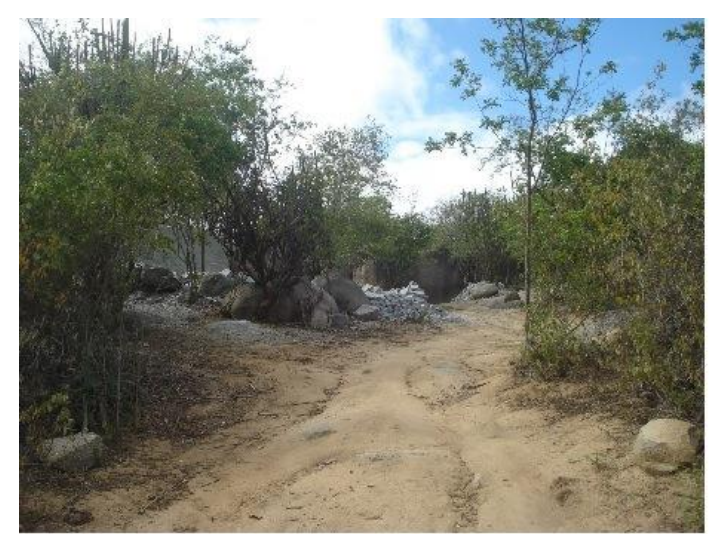

(b)

Figure 10 - Parallelepiped extraction in the Tanque Caboclo mining (a) and its location in the middle of the native vegetation (b).

The Figure 11 shows the classified areas with a high degree of environmental degradation, denominated areas that are involved in a land degradation process, located in the southwestern part (a and b) and southwest (c and d) of the municipality of Picuí.

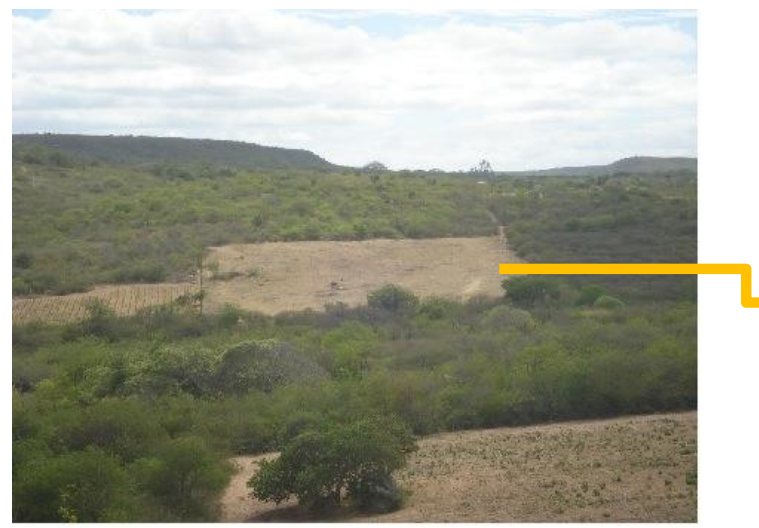

(a)

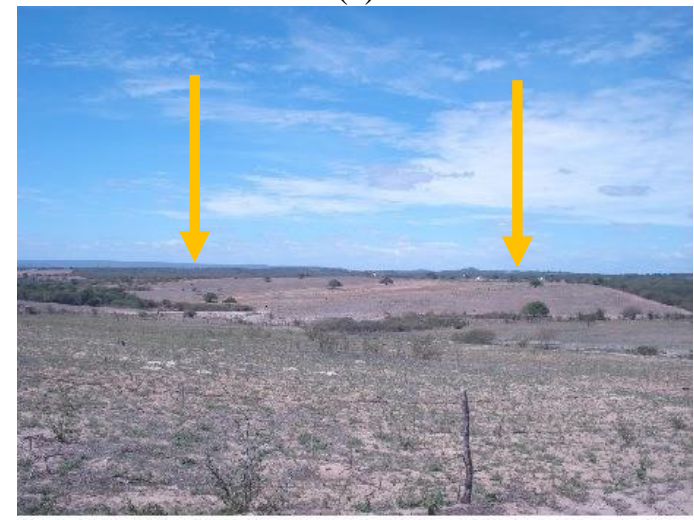

(c)

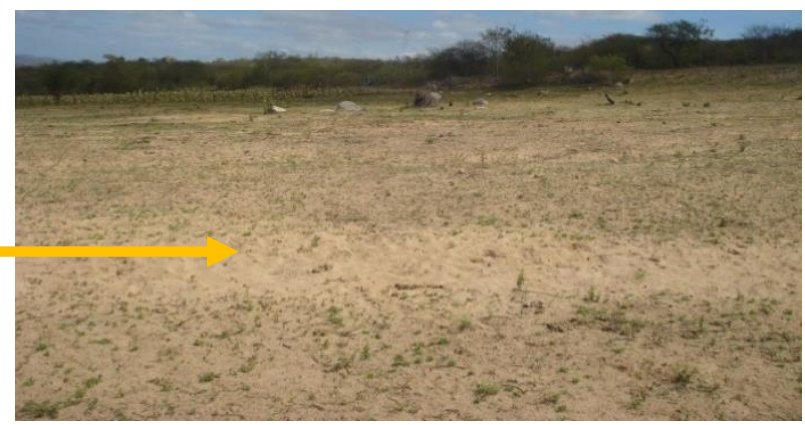

(b)

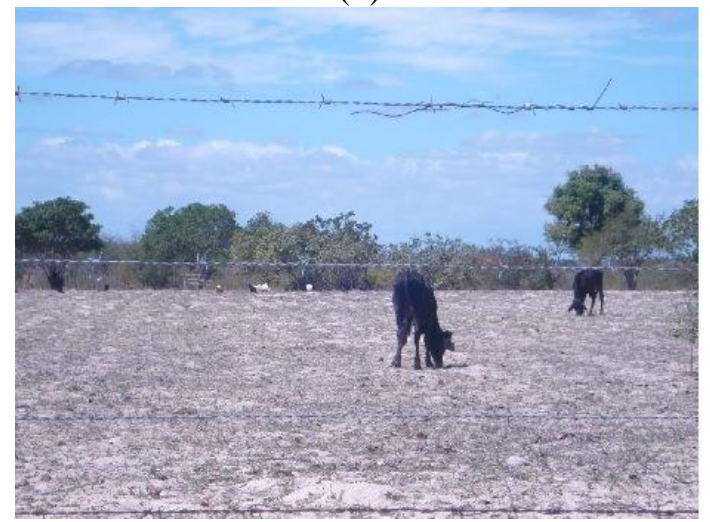

(d)

Figure 11 - Degraded areas (a) and (b) located near the Tanque do Caboclo digging in the southeast of the municipality, and cattle grazing in a severely degraded area (c) and (d) located in the southwest of the municipality of Picuí.

The lands environmental degradation presented in Figure 11 are not related to the degradation by digging, and in principle they are related to the lands degradation using the areas for the conventional agricultural crops, and agriculture by, mainly by means of the Agave monocultures (Agave sisalana, Perrine) and Cotton (Gossypium hirsutum, L.), through which the municipality past in the 1970s, 
1980s and 1990s. Besides this factor, can be verify when analyzing Picuí Altimetric Chart (Figure 2), that these areas are those whose relief has flatter areas.

The areas where the Caatinga has been preserved and whose areas have recovered are in the

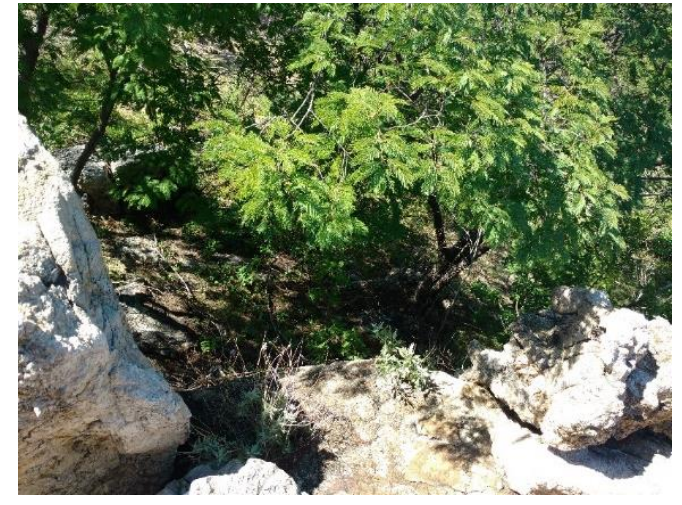

(a)

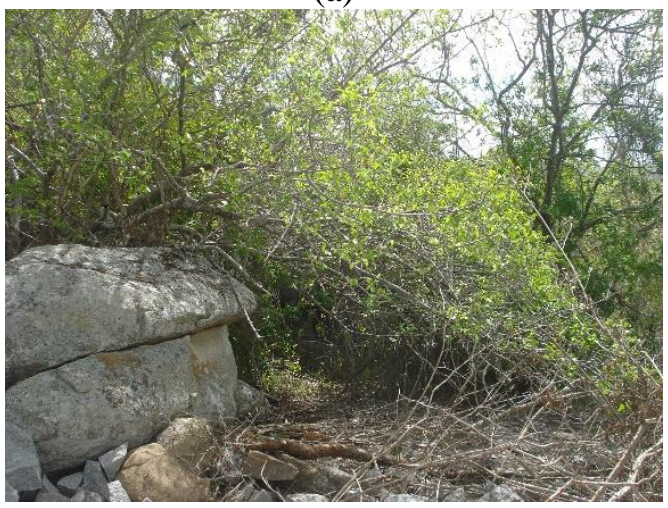

(c) higher areas where the climate is blander, and the availability of water from the processes of burlap decomposition and evapotranspiration, maintains moisture in the soil more intensely (Figure 12).

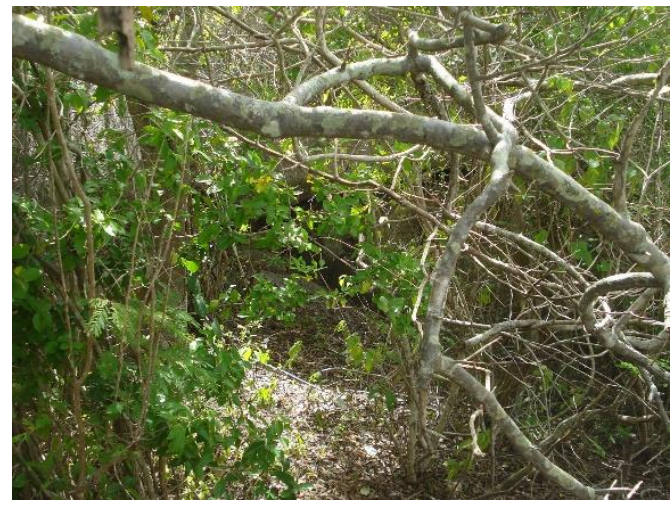

(b)

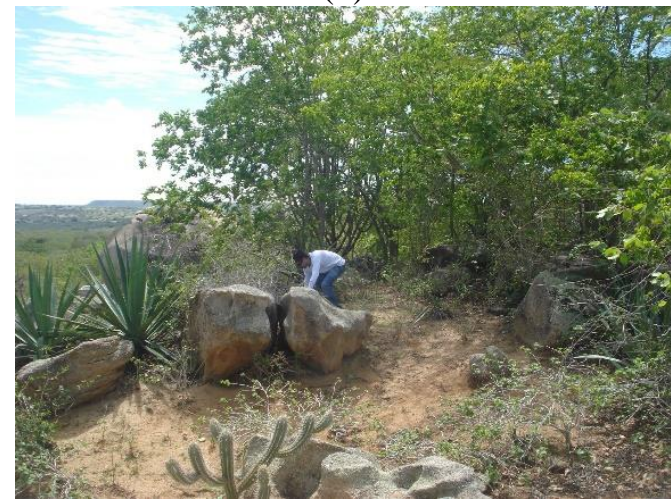

(d)

Figure 12 - Preserved areas (a) and (b) located in the highest regions of the municipality, and where vegetation recovered during the three decades of study $(\mathrm{c}$ and $\mathrm{d})$.

Figure 12 shows a Caatinga of shrub vegetation, of high to medium sized, which has a high density of species, present in higher regions, such as hilltops, where access becomes more difficult, consequently its removal for exploration also.

\section{Conclusions}

The article started from the principle of the establishment of the quantity of live biomass of the municipality of Picuí. Therefore, was considered the changes that occurred in the last three decades in the $\mathrm{n}$ the municipality to correlate all the socioeconomic, environmental and climatological factors that occurred during this time interval.

Initially, were realized procedures from satellite images, which characterized the municipality, and always represented the final condition of the 1990 , 2000 and 2010 decades. These TDI procedures provided parameters to assist in subsequent procedures to establish the NDVI, SAVI and IAF index calculations.
The Altimetric Chart generated allowed to correlate the degraded areas as areas with less geographical accidents, being, therefore, areas plane and propitious to the development of the agriculture by monoculture.

The degradation maps revealed how the use and occupation of soils and vegetation occurred in the three studied decades. It was verified as in the degradation maps, as in the vegetation indexes, that there was a decrease of the green areas between the first two decades of the study, evidenced by the scarce rains in the initial years of the 2000 decade, referenced with the climatologic data. In the

next decade, in 2010, vegetation increased considerably, due to the rains in the region, which was also demonstrated in the classification of vegetation indices, which showed an increase of almost half the vegetation cover of the municipality of Picuí and the decline of degraded areas over the last three decades.

The results also showed that vegetation and soil degradation occurred, but that these areas are recovering over the years. In any case, the most 
degraded areas are in the southeastern part of the municipality and, in principle are related to the degradation of the land by the use of the areas for agricultural cultivation and the areas where the vegetation is more present and preserved, and whose vegetative vigor presented better, are located in the northeastern areas of the municipality.

It was also observed that the main degradable activities carried out in the municipality are family farming and mineral extraction by mines, which brought about strong interventions in the Picuí vegetation cover.

Specifically, this work revealed the priority areas for intervention, for which it is urgent to develop policies for the recovery of degraded areas, in view of the need for awareness and the creation of diverse public policies.

Finally, it is concluded that the use of geotechnologies, as well as the indices related to vegetation, are important tools for the management, characterization and use and occupation of the soil.

\section{References}

Accioly, L.J.d O., Pacheco, A., Costa, T.C.C., Lopes, O.F., Oliveira, M.A.J., 2002. Relações empíricas entre a estrutura da vegetação e dados do sensor TM/LANDSAT. Revista Brasileira de Engenharia Agrícola e Ambiental 6, 492-498.

Boegh, E., Soegaard, H., Thomsen, A., 2002. Evaluating evapotranspiration rates and surface conditions using Landsat TM to estimate atmospheric resistance and surface resistance. Remote Sensing of Environment 79, 329-343.

Eastman, J.R., 2006. Idrisi Andes - Guide to GIS and Image Processing. Clark Laboratory. Clark university, Worcester.

FAO. Food and Agriculture Organization of The United Nations, 2005. Convenção das Nações Unidas de Combate à Desertificação nos países afetados por seca grave e/ou desertificação, particularmente na África (CCD). Folheto explicativo - FAO. Disponível: http://www.fao.org/desertification /default.asp?lang=sp>. Acesso: 11 out. 2005.

Fontana, D.C., Berlato, M.A., Bergamaschi, A., 1988. Relação entre índice de vegetação global e condições hídricas no Rio Grande do Sul. Pesquisa Agropecuária Brasileira 33, 1399-1405.

Gilabert, M.A, González-Piqueras, J, García-Haro, F.J, Melia, J., 2002. A generalized soil-adjusted vegetation índex. Remote Sensing of Environment 82, 303-310.

Huete, A.R., 1988. A soil-adjusted vegetation index.
Remote Sensing of Environment 25, 295-309.

IBGE. Instituto Brasileiro de Geografia e Estatística. Censo demográfico 2010. Disponível: http://www.sidra.ibge.gov.br. Acesso: 3 dez. 2013.

Matallo Junior, H., 2001. Proposta de um sistema básico de indicadores para identificação e monitoramento dos processos de desertificação na América Latina e Caribe: versão resumida. Anexo II, in: Indicadores de desertificação: histórico e perspectivas. UNESCO, Brasília.

Melphi, A.J., 2004. Prefácio, in: Philippi Jr, A., Romêro, M.deA., Bruna, G.C. (Eds.). Curso de Gestão Ambiental. Manole, Baureri, pp. xix-xx.

Moreira, M.A., Assunção, G.V., 1997. Princípios Básicos, Metodologias e Aplicações de Sensoriamento Remoto na Agricultura. INPE, São Jose dos Campos.

PAN-BRASIL. Programa de Ação Nacional de Combate à Desertificação e Mitigação dos Efeitos da Seca, 2005. Ministério do Meio Ambiente, Brasília-DF.

Rouse, J.W., Haas, R.H., Schell, J.A., Deering, D.W., 1973. Monitoring vegetation systems in the Great Plains with ERTS. Symposium of ERTS, Greenbelt.

Silva, B.B., Lopes, G.M., Azevedo, P.V., 2005. Determinação do albedo de áreas irrigadas com base em imagens LANDSAT 5-TM. Revista Brasileira de Agrometeorologia 13, 11-21.

Silveira, T.A., Henriques, A.A., Dantas, M.M.M., Pereira, F.C, Ferreira, J.R.S., Sousa, F.A.S., 2013. Estimativa das áreas em processo degradação ambiental por garimpo e agricultura no município de Picuí - PB. Congreso Latinoamericano de Agroecología -SOCLA, Perú.

Sousa, R.F.de, 2007. Terras agrícolas e o processo de desertificação em municípios do semi-árido paraibano. Tese (Doutorado). Campina Grande, UFCG.

SUDEMA-PB. Superintendência de Desenvolvimento e Meio Ambiente da Paraíba, 2008. Disponível: http://www.sudema.pb.gov.br. Acesso: 29 maio 2008.

UNITED NATIONS, 2001. Text of the United Nations Convention to Combat Desertification. Disponível: www.unccd.int/convention/text/convention.php. Acesso: 25 Set. 2001.

Watson, D.J., 1947. Comparative physiological studies on growth of fields crops. I - Variation in net assimilation rate and leaf area between species and varieties, and within and between years. Annals of Botany 11, 41-76. 